\title{
Study the effect of khazra iron nano chelate fertilizer foliar application on two rapeseed varieties
}

Hasan H. Mahdi ${ }^{1}$, Lamiaa A. Mutlag ${ }^{1}$ and Raghad S. Mouhamad ${ }^{1 *}$,

DOI. 10.21931/RB/2019.04.02.4

Abstract: An experiment was conducted in Al-zafraniya station / Baghdad - Iraq, during the winter season 2017 - 2018 in order to study the effect of khazra iron nano chelate fertilizer foliar application on two rapeseed varieties for increasing yield and yield components. The experiment designed by randomized complete blocks design (RCBD) for three replicates. The first factor included two rapeseed varieties (Brassica napus var. oleifera and Brassica napus $\mathrm{L}$. var. pactol) and second factor included khazra iron nano chelated in three levels 0,5 (kg.ha-1) $(0.5 \mathrm{~kg}$ nano iron fertilizers per 1000-liter water) and 10 (kg.ha-1) (1 kg nano iron fertilizers per 1000-liter water). Means of the treatments was compared with a significant difference in the use of the least significant difference (LSD) at the probability level $(p \leq 0.05)$. Results showed that effect of khazra iron nano chelate foliar application, rapeseed varieties and interaction of them had significant effects on yield, biological yield and total dry biomass, which were 1298.6 (kg.ha-1), 7900 (kg.ha-1) and 7288 (kg.ha-1) respectively, at level (kg.ha-1) for rapeseed (Brassica napus var. oleifera). While rapeseed (Brassica napus L. var. pactol) only had biological yield and total dry biomass which were $4260 \mathrm{~kg}$. ha-1 and 4460 (kg.ha-1) respectively. This is due to the genetic nature of each plant species. According to the results, rapeseed (Brassica napus var. oleifera) with 10 (kg.ha-1) khazra iron nano chelate fertilizer foliar application had the highest values at most of evaluated characters.

Keywords: Nano khazra iron chelate fertilizer, yield, varieties, biological yield, rapeseed

\section{Introduction}

In the previous studies using khazra iron nano chelate zinc and manganese, supplements had the potential role in iron fertilizer ${ }^{1}$. In another study ${ }^{2}$, the influence of khazra iron nano chelate fertilizer on rice yield was examined and was shown that applied treatments have a significant effect on all characteristics except grain thousand weigh. Results show that wet weight and maximum leaf area index is influenced by the concentration of khazra iron nano chelate fertilizer and influence dry weight for both types of spinach. Using $4 \mathrm{~kg}$. ha ${ }^{-1}$ khazra iron nano chelate fertilizer causes 58 and $47 \%$ increase in wet weight and maximum leaf surface index, respectively comparing to use of no fertilizer in wheat plant ${ }^{3}$. The investigating the effect of khazra iron nano chelate foliar application of amino acids and nanoparticles and chelated iron on photosynthetic pigments and yield of potato ${ }^{4}$. The interactive effect of amino acid and iron fertilizer indicated that application of amino acid, foliar application, and soil application of iron nano chelate had the best effects on chlorophyll a, total chlorophyll, and tuber yield. Other results indicated that both forms of khazra iron nano chelate fertilizer increased leaf chlorophyll concentration, compared to other spraying treatments and the control 5. Application of nano-forms of fertilizers, compared to chemical forms of fertilizers, increased the phosphorus concentration, biomass, and crude protein and soluble carbohydrate concentration.

Winter rapeseed starts growing early in the spring. Therefore, after the snow falls, it is necessary to survey winter rapeseed crops in order to establish the preservation of plants. ${ }^{6,7}$. Apart from its role in direct feeding by humans and animals, it has expanded globally industrial use, including oil producing factories or as a source of biofuel in recent years ${ }^{8}$. Higher yield per unit area can be achieved by improving modern cultural practices with better macro and micronutrient management ${ }^{9}$.
Recent research has shown that a small number of nutrients, especially Zn, Fe, and Mn applied by foliar spraying significantly increased the yield of crops ${ }^{10,11}$. Narimani and others reported that foliar application of microelements improved the effectiveness of macronutrients ${ }^{12}$. Effect of iron and zinc on micronutrient levels in wheat (Triticuma estivum L.) are defined substances that are significant crop growth; however, they are used in lower amounts as compared to macronutrients, such as N, P and $\mathrm{K}^{13}$.

\section{Materials and methods}

The experiment carried out in Al-zafraniya station / Baghdad - Iraq, during the winter season (2017 - 2018). The factorial experiment that consists of two factors and with three replicates was designed by randomized complete blocks design (RCBD). The first factor consisted of two rapeseed varieties (Brassica napus var. oleifera and Brassica napus L. var. pactol) and second factor was three levels of khazra iron nano chelate fertilizer foliar application $0,5 \mathrm{~kg}$. ha- ${ }^{-1}(0.5 \mathrm{~kg}$ khazra iron fertilizers per 1000 -liter water $)$ and $10 \mathrm{~kg} . \mathrm{ha}^{-1}(1 \mathrm{~kg}$ khazra iron fertilizers per 1000 -liter water). Rapeseed varieties were planted in a row with spacing $30 \mathrm{~cm}$ in plot $(1 \times 2) \mathrm{m}^{2}$; the plots were separated by $0.5 \mathrm{~m}$ in width from all sides to avoid the effect of fertilization. The iron nano chelate fertilizer sprayed after one month of agriculture on leaf and branch of studied cultivars. Triple superphosphate added as a phosphate resource at the sowing time and urea as a nitrogen resource at sowing and tillering stages, as recommended. Soil properties of the area under study showed in table 1 .

Table 1: Soil properties of the area under study

\begin{tabular}{|c|c|c|c|c|c|c|}
\hline pH & EC ds/int & Sed lextare & OMS: & N\% & $P=g k g^{1}$ & $\mathrm{~K} m \mathrm{~kg} \mathrm{~g}^{2}$ \\
\hline 71 & 6 & silt clay loam & 131 & 0.18 & 25.56 & 590 \\
\hline
\end{tabular}


After physiological ripening biological yield were determined by draining of whole plants, which were harvested at $2 \mathrm{~m}^{2}$ of the center of each plot at $75^{\circ} \mathrm{C}$ for $48 \mathrm{~h}$, an oven. For evaluation of grain yield after measurement of biological yield, spikes were removed from stems, and after winnow, net gain weight were determined. In order to determine of chemical and physical properties of farm soil samples were prepared from 0-30 $\mathrm{cm}$ depth. Samples were sieved and were analyzed at the laboratory.

The contents of the mineral elements for $\mathrm{Ca}, \mathrm{Na}, \mathrm{Mg}, \mathrm{Mn}, \mathrm{K}, \mathrm{Zn}$ $\mathrm{Cu}$ and $\mathrm{Fe}$ in soil determined using the DTPA method and analyzed by Atomic Absorption Spectroscopy (AAS). Electrical conductivity values were determined by EC meter in 1:1 soil-water mixture ${ }^{14}$ $\mathrm{pH}$ was determined by a glass electrode $\mathrm{pH}$ meter calibrated with a standard solution in a 1:1 soil-water mixture ${ }^{15}$. Available of the phosphorus (P) determined by the ascorbic acid method of $882 \mathrm{~nm}$ in a spectrophotometer ${ }^{16}$. N percentage determined by the Kjeldahl method. The Organic matter $(\mathrm{OM})$ determined by Wakley - Black method ${ }^{17}$. The Soil texture determined by reading the hydrometer in water mixture for 40 seconds and 2 hours 18 . The contents of the mineral elements for $\mathrm{Ca}, \mathrm{Na}, \mathrm{Mg}, \mathrm{Mn}, \mathrm{K}, \mathrm{Zn}$, $\mathrm{Cu}$ and $\mathrm{Fe}$ in the plant determined using the digestion method and analyzed by Atomic Absorption Spectroscopy (AAS). Khazra fertilizer analyzed by $\mathrm{x}$-ray fluorescence (XRF) techniques; table 2 shows the XRF analysis of khazra fertilizer.
Data were subjected to analysis of variance using SAS and EXCEL software. The differences between the means were compared by the least significant difference test (LSD) $(\mathrm{p} \leq 0.05)$.

\section{Results and discussion}

Khazra iron nano chelate fertilizer: Khazra iron nano chelate had the strong and stable complex with $3<\mathrm{pH}<11$ range and make $9 \%$ of solved iron in water available for the plant. Zinc and manganese supplements had a specific role in this fertilizer ${ }^{19}$. The results showed increases in micronutrient essentials elements such as Zinc, Iron, Manganese, Sodium, and Sulphur (table 2). Using khazra iron chelate enhances the process of photosynthesis as well as the speed of food preparation within plant leaves, and increases the number of sprouts and flowers, leading to the height of crop volume and speed of productivity in plants ${ }^{20}$. The presence of sulfur in khazra complex is one of its many advantages over similar fertilizers, as sulfur partially acidifies the unsuitable and alkaline soil and increases the absorption rate of microelements such as Iron, Manganese and Zinc ${ }^{21}$

\begin{tabular}{|c|c|c|c|c|c|}
\hline Element & Symbol & Conc. $\mathrm{mg} \mathrm{kg} \mathrm{kg}^{-1}$ & Element & Symbol & Conc. $\mathrm{mg} \mathrm{kg}{ }^{-1}$ \\
\hline Sodium & $\mathrm{Na}$ & 3300 & Selenium & $\mathrm{Se}$ & 0.3 \\
\hline Magnesium & $\mathrm{Mg}$ & 530 & Bromine & $\mathrm{Br}$ & 0.5 \\
\hline Aluminum & Al & 130 & Rubidium & $\mathrm{Rb}$ & 0.3 \\
\hline Silicon & Si & 60 & Strontium & $\mathrm{Sr}$ & 2.1 \\
\hline Phosphorus & $\mathrm{P}$ & 158 & Yttrium & $\mathrm{Y}$ & 7 \\
\hline Sulfur & $\mathrm{S}$ & 44370 & Molybdenum & Mo & 20 \\
\hline Chlorine & $\mathrm{Cl}$ & 3.2 & Silver & $\mathrm{Ag}$ & 3.2 \\
\hline Potassium & $\mathrm{K}$ & 27 & Cadmium & Cd & 3.6 \\
\hline Calcium & $\mathrm{Ca}$ & 204 & Tin & Sn & 13.7 \\
\hline Titanium & $\mathrm{Ti}$ & 8.5 & Antimony & $\mathrm{Sb}$ & 7.5 \\
\hline Vanadium & V & 5.8 & Tellurium & $\mathrm{Te}$ & 5.8 \\
\hline Chromium & $\mathrm{Cr}$ & 68 & Iodine & I & 28.4 \\
\hline Manganese & Mn & 207.8 & Barium & $\mathrm{Ba}$ & 82.2 \\
\hline Iron & $\mathrm{Fe}$ & 35300 & Tungsten & W & 3.9 \\
\hline Cobalt & $\mathrm{Co}$ & 16.1 & Mercury & $\mathrm{Hg}$ & 1.1 \\
\hline Nickel & $\mathrm{Ni}$ & 21.2 & Thallium & $\mathrm{TI}$ & 1.3 \\
\hline Copper & $\mathrm{Cu}$ & 11.5 & Lead & $\mathrm{Pb}$ & 3 \\
\hline Zine & $\mathrm{Zn}$ & 31.4 & Bismuth & $\mathrm{Bi}$ & 1 \\
\hline Gallium & Ga & 0.8 & Thorium & Th & 1.2 \\
\hline Germanium & Ge & 0.4 & Uranium & $\mathrm{U}$ & 1.3 \\
\hline Arsenic & As & 0.9 & & & \\
\hline
\end{tabular}


The results in table 3 show increasing significantly in the seed yield $1298.6 \mathrm{~kg}$. ha ${ }^{-1}$ for rapeseed (Brassica napus var. oleifera) at a level of $10 \mathrm{~kg}$. ha ${ }^{-1}$. While, rapeseed (Brassica napus L. var. pactol) not has, seed yield. The status of seed yield is the most important field scale. The high seed yield for winter rapeseed (Brassica napus var. oleifera) may be due to increasing the number of capsules in the plant, the number of seeds in capsules and response to khazra iron nano chelate fertilizer and adaptation for climatic conditions. Rezaeei et al. ${ }^{22}$ according to results, using of khazra iron nano chelated fertilizer foliar application at $2.5 \%$ increased grain yield for wheat in drylands. Nazaran et al. ${ }^{23}$ in order to study the effect of khazra iron nano chelated fertilizer application on quantitative and quality of wheat an experiment was arranged and results showed that khazra iron nano chelated fertilizer foliar application at shooting stage let to $99 \%$ increasing of grain yield. The rapeseed (Brassica napus L. var. pactol) not have seed yield can be explained by non-response to khazra iron nano chelate fertilizer and non-adaptation to climatic conditions.

As shown in table 3, the results of an increase in nano-Fe concentration increased biological yield. The rapeseed (Brassica napus var. oleifera) has $7900 \mathrm{~kg}$. ha- ${ }^{-1}$ at level of $10 \mathrm{~kg}$. ha ${ }^{-1}$. The
Table 3 shows increasing significantly in the total dry biomass $7288 \mathrm{~kg}$. ha- $\mathrm{h}^{-1}$ for rapeseed (Brassica napus var. oleifera), While the rapeseed (Brassica napus L. var. pactol) had total dry biomass $4260 \mathrm{~kg}$. ha ${ }^{-1}$ at level of $10 \mathrm{~kg}$. ha- ${ }^{-1}$. This may be due to increased growth rates of cells in number and volume, which lead to increased carbonation and dry matter production ${ }^{27}$. Dry matter in field crops is the result of the accumulation of net carbon representation during the growing season. Which is the result of the efficiency of vegetation in the interception of solar radiation as the dry weight of the plant generally increases slowly in the early stages of growth and continues to increase in the plant growing season and then decrease with time ${ }^{28}$. That is similar find in report peyvendi et al. ${ }^{29}$, the highest mean dry and fresh weight of stems; roots and leaves were obtained in the nano-iron chelated treatment.

The nutrient content of leaves: in this study, adding khazra iron nano chelate fertilizer to winter rapeseed varieties significantly affected the contents nutrients in leaves (table 4). This is due to the genetic nature of each plant species, which in turn determines phenotypic properties, internal content, growth, and specific conditions 28 .

The rapeseed (Brassica napus L. var. pactol) have the highest

\begin{tabular}{|c|c|c|c|c|c|c|}
\hline \multirow[t]{4}{*}{ Parameter } & \multicolumn{6}{|c|}{ Khazra fertilization } \\
\hline & \multicolumn{2}{|c|}{$0 \mathrm{~kg} \cdot \mathrm{ha}^{-1}$} & \multicolumn{2}{|c|}{$5 \mathrm{~kg} \cdot \mathrm{ha}^{-1}$} & \multicolumn{2}{|c|}{$10 \mathrm{~kg} \cdot \mathrm{ha}^{-1}$} \\
\hline & \multicolumn{6}{|c|}{ rapeseed varieties } \\
\hline & $\begin{array}{c}\text { (Brassica napus } \\
\text { var. oleifera) }\end{array}$ & $\begin{array}{l}\text { (Brassica napus } \\
\text { L. var. Pactol) }\end{array}$ & $\begin{array}{c}\text { (Brassica napus } \\
\text { var. oleifera) }\end{array}$ & $\begin{array}{l}\text { (Brassica napus } \\
\text { L. var. Pactol) }\end{array}$ & $\begin{array}{c}\text { (Brassica napus } \\
\text { var. oleifera) }\end{array}$ & $\begin{array}{l}\text { (Brassica napus } \\
\text { L. var. Pactol) }\end{array}$ \\
\hline Yield $\left(\mathrm{kg} \mathrm{ha}^{-1}\right)$ & $566.2^{\mathrm{a}}$ & 0 & $898.5^{\mathrm{b}}$ & 0 & $1298.6^{\mathrm{b}}$ & 0 \\
\hline $\begin{array}{l}\text { Biological yield } \\
\left(\mathrm{kg} \mathrm{ha}^{-1}\right)\end{array}$ & $3570^{\mathrm{a}}$ & $3120^{\mathrm{b}}$ & $6170^{c}$ & $4440^{\mathrm{d}}$ & $7900^{e}$ & $4460^{d}$ \\
\hline $\begin{array}{l}\text { Total dry biomass } \\
\left(\mathrm{kg} \mathrm{ha}^{-1}\right)\end{array}$ & $4011^{\mathrm{a}}$ & $3004^{b}$ & $5947^{c}$ & $4177^{d}$ & $7288^{e}$ & $4260^{f}$ \\
\hline
\end{tabular}

Table 3: The effect of Khazra fertilization $\left(0,5\right.$ and $10 \mathrm{~kg}$. ha- $\left.{ }^{-1}\right)$ on yield, biological yield and total dry biomass content of two rape varieties in Al-zafraniya station (2017-2018)

rapeseed (Brassica napus L. var. pactol) had $4460 \mathrm{~kg}^{-\mathrm{ha}^{-1}}$ at the level of $10 \mathrm{~kg}$. ha ${ }^{-1}$. In experiments conducted earlier, biological yield loss due to Fe deficiency has been reported Mahmoudi et al. ${ }^{24}$ [ Ziaeian and Malakoti ${ }^{25}$ compared the effect of Fe and manganese application in soil with the foliar application, and the combination of both, increased grain yield, biological yield, and protein content in wheat farms. The results are consistent with the findings of the research on the effect of micronutrient of iron on soybean seed ${ }^{26}$
$\mathrm{N} 1.11 \%, \mathrm{P} 0.56 \mathrm{mg} \mathrm{kg}^{-1}, \mathrm{~S} 1.6 \mathrm{mg} \mathrm{kg}^{-1}$, Fe $259 \mathrm{mg} \mathrm{kg}^{-1}$ and Mn $36.1 \mathrm{mg} \mathrm{kg}^{-1}$ at level of $10 \mathrm{~kg}$. ha ${ }^{-1}$. While the rapeseed (Brassica napus var. oleifera) has, N $1.09 \%, \mathrm{P} 0.44 \mathrm{mg} \mathrm{kg}$ ${ }^{1}$, S $1.38 \mathrm{mg} \mathrm{kg}{ }^{-1}$, Fe $246 \mathrm{mg} \mathrm{kg}^{-1}$ and $\mathrm{Mn} 30.6 \mathrm{mg} \mathrm{kg} \mathrm{kg}^{-1}$ at level of $10 \mathrm{~kg}$. $\mathrm{ha}^{-1}$. The efficiency of using nano fertilizer from nitrogen and phosphorus is very high, rapid release and absorption by plants, which reduces the loss of unwanted nutrients in soil, water and air by direct absorption and avoids nutrient interaction with soil, microorganisms, water and air ${ }^{29}$

\begin{tabular}{|c|c|c|c|c|c|c|}
\hline \multirow[t]{4}{*}{ Parameter } & \multicolumn{6}{|c|}{ Khazra fertilization } \\
\hline & \multicolumn{2}{|c|}{$0 \mathrm{~kg} \cdot \mathrm{ha}^{-1}$} & \multicolumn{2}{|c|}{$5 \mathrm{~kg} \cdot \mathrm{ha}^{-1}$} & \multicolumn{2}{|c|}{$10 \mathrm{~kg} \cdot \mathrm{ha}^{-1}$} \\
\hline & \multicolumn{6}{|c|}{ rapeseed varieties } \\
\hline & $\begin{array}{l}\text { (Brassica napus } \\
\text { var. oleifera) }\end{array}$ & $\begin{array}{l}\text { (Brassica napus } \\
\text { L. var. Pactol) }\end{array}$ & $\begin{array}{l}\text { (Brassica napus } \\
\text { var. oleifera) }\end{array}$ & $\begin{array}{l}\text { (Brassica napus } \\
\text { L. var. Pactol) }\end{array}$ & $\begin{array}{c}\text { (Brassica napus } \\
\text { var. oleifera) }\end{array}$ & $\begin{array}{l}\text { (Brassica napus } \\
\text { L. var. Pactol) }\end{array}$ \\
\hline \multicolumn{7}{|c|}{ macro-micro nutrients of leaves $\left(\mathrm{mg} \mathrm{kg}^{-1}\right)$} \\
\hline $\mathbf{N} \%$ & $0.76^{\mathrm{a}}$ & $0.97^{\mathrm{b}}$ & $1.01^{\mathrm{c}}$ & $1.09^{\mathrm{d}}$ & $1.09^{\mathrm{d}}$ & $1.11^{\mathrm{e}}$ \\
\hline $\mathbf{P}$ & $0.23^{\mathrm{a}}$ & $0.4^{\mathrm{b}}$ & $0.49^{c}$ & $0.53^{\mathrm{d}}$ & $0.44^{\mathrm{b}}$ & $0.56^{\mathrm{d}}$ \\
\hline $\mathbf{S}$ & $0.16^{\mathrm{a}}$ & $0.35^{b}$ & $0.65^{\mathrm{c}}$ & $1.16^{\mathrm{d}}$ & $1.38^{\mathrm{e}}$ & $1.6^{\mathrm{f}}$ \\
\hline Fe & $233^{\mathrm{a}}$ & $240^{\mathrm{b}}$ & $248^{c}$ & $254^{d}$ & $246^{\mathrm{C}}$ & $259^{\mathrm{d}}$ \\
\hline Mn & $24.1^{\mathrm{a}}$ & $27.1^{\mathrm{b}}$ & $29.8^{c}$ & $33.2^{\mathrm{d}}$ & $30.6^{c}$ & $36.1^{\mathrm{e}}$ \\
\hline
\end{tabular}


The nutrient content of roots: in table 5, adding khazra iron nano chelate fertilizer to rapeseed varieties significantly affected the content of nutrients in roots. The rapeseed (Brassica napus L. var pactol) have the highest $\mathrm{N} 1.31 \%, \mathrm{P} 0.46 \mathrm{mg} \mathrm{kg}^{-1}, \mathrm{~S} 1.06 \mathrm{mg} \mathrm{kg}^{-1}$,

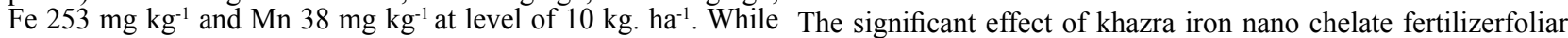
the rapeseed (Brassica napus var. oleifera) had, N 1.19\%, P 0.34 application at level $10 \mathrm{~kg}$.ha-1 to rapeseed (Brassica napus var. $\mathrm{mg} \mathrm{kg}$, $\mathrm{S} 0.88 \mathrm{mg} \mathrm{kg}^{-1}, \mathrm{Fe} 243 \mathrm{mg} \mathrm{kg}^{-1}$ and $\mathrm{Mn} 31 \mathrm{mg} \mathrm{kg}^{-1}$ at oleifera) show increase in the majority of the studied traits; yield, level of $10 \mathrm{~kg} \cdot \mathrm{ha}^{-1}$. Results show the nutrient content in roots of biological yield and total dry biomass. Rapeseed (Brassica napus

two rapeseeds varieties at different levels of nano fertilizer was L. var. pactol) only has total dry biomassandbiological yield. The directly proportional to the increase in the level of fertilizer.

\begin{abstract}
Conclusion rapes(Brassica napus L. var. Pactol) was significantly outweighed the (Brassica napus var. oleifera) in the nutrient content of leafs
\end{abstract} and roots $(\mathrm{N}, \mathrm{P}, \mathrm{S}, \mathrm{Fe}$ and $\mathrm{Mn})$.

rapeseed varieties

\section{(Brassica napus} var. oleifera)

\section{(Brassica napus} L. var. Pactol)

\section{(Brassica napus} var. oleifera)
(Brassica napus
(Brassica napus var. oleifera)
(Brassica napus L. var. Pactol) macro-micro nutrients of roots ( $\mathrm{mg} \mathrm{kg}^{-1}$ )

\begin{tabular}{|c|c|c|c|c|c|c|}
\hline $\mathrm{N} 90$ & $0.51^{2}$ & $0.76^{b}$ & $1.11^{\circ}$ & $1.19^{d}$ & $1.19^{4}$ & $1.31^{t}$ \\
\hline $\mathbf{P}$ & $0.19^{a}$ & $0.32^{6}$ & $0.39^{\circ}$ & $0.44^{d}$ & $0.34^{\mathrm{b}}$ & $0.46^{d}$ \\
\hline $\mathbf{S}$ & $0.11^{2}$ & $0.24^{b}$ & $0.47^{6}$ & $0.77^{d}$ & $0.88^{e}$ & $1.06^{f}$ \\
\hline Fe & $222^{2}$ & $235^{b}$ & $241^{c}$ & $250^{d}$ & $243^{c}$ & $253^{d}$ \\
\hline $\mathrm{Mn}$ & $17^{x}$ & $21.1^{b}$ & $30.8^{e}$ & $35^{d}$ & $31^{\mathrm{c}}$ & $38^{\circ}$ \\
\hline
\end{tabular}

Table 5: The effect of Khazra fertilization $\left(0,5\right.$ and $10 \mathrm{~kg}$. ha- $\left.{ }^{-1}\right)$ on the nutrient content of the root of two rape varieties in Al-zafraniya station (2017-2018). Values marked with the same letter do not differ significantly at $\mathrm{p} \leq 0.05$

\section{References}

1 Khaje, Poor, M.R. Principles of Agriculture, Second Edition, published by Jahad Daneshgahi, Univ. Isfahan. 1998.

2. Baghaie, N., Keshavarz, N., Nazaran, M.H.1thNational Conference on new topics in agriculture,8-10 November,University of Saveh, Iran,Saveh. 2011

3. Barrett, S.H. and Kohn, J.R., 1991. Genetic and evolutionary consequences of small population size in plants: implication for conservation. In: Falk D.A. and Holsinger, K.E. (eds), Genetics and Conservation of Rare Plants, Oxford University Press, New York, pp: 3-30.

4. Roozbahani, A., Ali, S. Evaluation Amino Acids and Iron Nano particles on Photosynthetic Pigments and Yield of Potato. J. Crop. Nut. Sci., 1(1):7-14.2015.

5. Mohammadi, K. and Rokhzadi, A. Effect of seed priming and foliar application with micronutrients on quality of forage corn (Zea mays). Environmental and Experimental Biology, 14, pp.151-156. 2016. 6. Malhi, S.S., and Gill K. S. "Interactive effects of $\mathrm{N}$ and S fertilizers on canola yield, seed quality, and uptake of S and N", Canadian Journal of Plant Science, Vol. (87), pp. 211-222. 2007.

7. Negawer, E. A. and Mahfouz S. A. "Response of canola (Brassica napus L.) to biofertilizers under Egyptian conditions in newly reclaimed soil", International Journal of Agricultural Science, Vol. (2), No. 1, pp. 12-17. 2010.

8. Kandil, A.A., Sharief, A.E. Abido, W.A.E. and Ibrahim, M.M.O. "Response of some canola cultivars (Brassica napus L.) To salinity stress and its effect on germination and seedling properties", Journal of Crop Science, Vol. (3), pp. 95-103. 2012.

9. Jan, M. T., and Khan, S. "Response of wheat yield components of N fertilizer their levels and application time", Pakistanian Journal of Biological Sciences, Vol. (3), pp. 1227-1230. 2000.

10. Sarkar, D. Mandal, B., and Kundu, M.C. "Increasing use efficiency of boron fertilizers by rescheduling the time and methods of application for crops in India", Plant and Soil, Vol. (301), pp. 77-85. 2007.
11. Wissuwa, M., Ismail, A.M. and Graham, R.D."Rice grain zinc concentrations as affected by genotype native soil-zinc availability, and zinc fertilization", Plant and Soil, Vol. (306), pp. 37-48. 2008.

12. Narimani, H., Rahimi, M.M., Ahmadikhah, A. and Vaezi, B."Study on the effects of foliar spray of micronutrient on yield and yield components of durum wheat". Archives of Applied Science Research, Vol. (2), pp. 168-176. 2010.

13. Ai-Qing, Z., Qiong-Li, B., Xiao-Hong, T., Xin-Chun, L., and Gale W. J. "Combined effect of iron and zinc on micronutrient levels in wheat (Triticumaestivum L.), J Journal of Environmental Biology, Vol. (32), pp. 235-239. 2011.

14. Page AL, Miller RH, Kenney DR. Method of Soil Analysis, 2nd (ed) Agron. 9, Publisher, Madiason, Wisconsin, 1982.

15. Mclean, E.O. Soil pH and Lime requirement. In: Methods of soil analysis Part2.Agronomy A.L. Page (ed) Am.Soc. Agron. Madison, 101. USA:199-234.1982.

16. Olsen, S. R., \& Sommers, L. E. Phosphorus. In A. L. page et al., (ed) Methods of soil analisis, 2nd ed. Agronomy 9:403-430.1982.

17. Nelson, D.w. AND 1.e. Sommers. Total x carbon, Organic carbon and organic Matter.

Methods of soil analysis. Part 2. Chemical and Microbiological properties. ASA, Madison.WI:359-580.1982.

18. Gee.G.W. and J.W. Bauder. Particle size analysis. In: Methods of Soil analysis.Part1. A.Klute (ed). Am.Soc. Agron. Madison 101. USA: 383-41.1986.

19. Khalaj H., Labaffi Hossein Abadi M.R. Nazaran M.H., Sheibani K. and Razazi A. 2008. Application of nano-organic fertilizer, foliar fertilizer and chelated iron on the apple and pear yield.

20. Sodour A.S.C. The technology owner and sole producer of chelated Nano fertilizers in the world. Unit 2, NO. 1, Iran. 2003.

21. Rezaeei, M., Daneshvar, M. and Shirani, A.H., 2014. Effect of iron nano chelated fertilizers foliar application on three wheat cultivars in 
Khorramabad climatic conditions. Scientific Journal of Crop Science, 3(2), pp.9-16

22. Nazaran, A., Pardakhti, M., Hokm Abadi, H., Ashtiani, M., 2005. The role of green space in reducing air pollution and the effect of iron chelate fertilizer Khazra' increase the efficiency of new plants. First Env. Eng. Conf.

23. Mahmoudi H, Ksouri R, Gharsalli M, Lachaâl M. 2005. Differences in responses to iron deficiency between two legumes: lentil (Lens culinaris) and chickpea (Cicer arietinum). Journal of plant physiology $162,1237-1245$.

24. Ziaeian A, Malakoti M.2001. Determination of critical level of Iron $(\mathrm{Fe})$ in wheat farms and its effects on the yield and grain fortification in highly calcareous soils of Iran. IranianJournal of Soil and Water Sciences (Special issue: Agronomy) 12, 45-56.

25. Sheshbahr, M. and M. Movahedidehnoodi. 2012. The effect of foliar application of zinc and iron on soybean seed vigor grown under drought stress. J. Crop Prod. 5(1): 19-35.
26. Issa, A. T. Physiology of Crop Plants, Press of the Ministry of Higher Education and Scientific Research, University of Baghdad. Number of pages: 496. 1990.

27. Peyvendi M., Parande H., Mirza M. 2011. Comparison of the effects of nano-iron chelated with iron chelate on growth parameters and antioxidant enzyme activity of Ocimum basilicum. New Cell Mol. Biotech. Mag. 1: 89-98. 2011.

28. Barrett, S.H. and Kohn, J.R., 1991. Genetic and evolutionary consequences of small population size in plants: implication for conservation. In: Falk D.A. and Holsinger, K.E. (eds), Genetics and Conservation of Rare Plants, Oxford University Press, New York, pp: 3-30.

29. DeRosa, M.C.; Monreal, C.; Schnitzer, M.; Walsh, R. and Sultan, Y., 2010. Nanotechnology in fertilizers. Nat. Nanotechnol., 5(2): 91-93

\section{Received: 8 April 2019}

Accepted: 30 April 2019 